\title{
Frameworks for citizens participation in planning: From conversational to smart tools
}

\author{
Donagh Horgan and Branka Dimitrijevic
}

\begin{abstract}
The paper concentrates on tools and technologies used for participatory processes in sustainable urban planning. Scotland's Place Standard, BREEAM-Communities assessment tool and the Smart City technologies for co-production in urban planning and design are analysed through literature review. Aktivniy Grazhdanin, a citizen engagement portal, established to devolve decision-making on aspects of Moscow's urban planning to citizens, provides a case study on the potential use of online tools to solicit citizens' views on the city management and transformation. Tools were selected as they provide participatory frameworks for developing consensus among decision makers and stakeholders on planning strategy, but use different methods - Scotland's Place Standard initiates a dialogue with interested groups; BREEAM-Communities includes a consultation with stakeholders at a later stage; and Aktivniy Grazhdanin attempts to solicit stakeholders' views by using online tools. Comprehensive criticism in the research of Kitchin (2014) and Angelidou \& Psaltoglou (2017) identified themes around ownership, governance and participation that informed the line of questioning in the case study. The research highlights the strengths and weaknesses of the analysed tools. It recommends how frameworks can be best shaped by such tools to achieve local ownership and provide structure for a more inclusive urban planning.
\end{abstract}

Key words: social innovation frameworks; engagement tools; citizen participation, smart city technologies; architecture

\section{Introduction}

Since the late nineteenth century, the profession of planning has evolved in order to develop advocacy and guidance for both communities and developers engaged in urban design and place-making. Across the developed world, behaviours that govern actors involved in spatial development in order to safeguard public assets and community cohesion have changed (Wainwright, 2014). Often planners have sought solutions to society's ills - poverty and ill-health - through the development process, placing their faith in the bricks and mortar of buildings (Jacobs, 1961), sometimes ignoring the root causes of social deprivation in order to respond to shifting short-termist public policy context at the time of urban development planning (Finger, 2018; Greenfield, 2017). Early twentiethcentury visionaries such as Ebenezer Howard and Robert Moses looked to megadevelopment projects and grand gestures as mechanisms for regeneration and rebirth in communities, developing new language and professionalism to build the theory of their practice (Jacobs, 1961).

Sustainable urban planning and design are increasingly dependent on social innovation, a term given to a variety of methodologies, tools and processes that support a multidisciplinary approach to urban transformation (Angelidou et al, 2017). The EU-funded TEPSIE project arrived at a core definition for social innovation as "new solutions... that simultaneously meet a social need (more effectively than existing solutions) and lead to new or improved capabilities and relationships and better use of assets and resources" (CaulierGrice et al, 2012). Similar definitions are used to describe the concept in much of the recent 
literature, building on experience of collaboration among networks, policymakers and practitioners in the field (Mulgan, 2006; Mulgan et al, 2007; Phills et al, 2008; Johannessen, 2013; Ruiz and Para, 2013; Angelidou and Psaltoglou, 2017). Alongside other types of innovation, social innovation is characterised by a collaborative approach of working towards a transformational impact in society. While not a novel concept in itself, it has gained popularity in the wake of the global financial crisis, as a way to develop more usercentred, sustainable social infrastructure through cross-sector partnerships. Although, it is also increasingly criticised as an extension for neoliberal reforms in the public sector (Massey and Johnston-Miller, 2016).

By definition, social innovation is something that is collaborative - meaning that it requires input from a number of (often isolated) actors, sectors, domains or knowledge areas working together towards a common goal (Horgan and Dimitrijević, 2018). Taking a hypothesis that social innovation occurs over phases of the network, framework and architecture (Horgan and Dimitrijević, 2018), this paper examines how collective approaches to urban design can inform more holistic policy development and inclusive growth.

Reminiscent of theories to support design thinking and process, a network develops around a social need, arising from social, economic or environmental challenges. If ideas and solutions are shared across this network, sharing contributes to an overarching framework, or strategy for sustainable development. Based around an open and agile interpretation of this framework, what may emerge is a set of innovative architectures - urban design solutions, digital environments and social service infrastructure that work in concert to promote greater community resilience. This hypothesis resonates with the view that community and built environment infrastructure should not be designed in isolation but conceived of together in order to develop genuine social value and achieve real social impact.

The idea of social innovation, defined as novel ideas that meet a social challenge (Manzini, 2014; Murray et al, 2010), can help us look outside of the established, sometimes restricted domains of single profession, looking to work with others to develop complex, multifaceted solutions that encompass a host of channels, infrastructures and professions. Bria et al (2015) conducted a far-reaching study to extensively document global social innovation initiatives, concluding that while there is an ever-increasing transdisciplinary movement of actors across technology and civil society collaborating on solutions to social challenges, more needs to be done to coordinate these actions and understand their implication for policy making and urban development.

Already two decades ago, discourse on sustainability in urban planning and design has brought into question the notion of adaptation for sustainability by asking whether we should be trying to sustain a status quo in situations or scenarios were the established modus operandi is no longer 'fit for purpose' (Marcuse, 1998). This is particularly relevant in the field of the built environment, given the lack of innovation in design, practice and materiality (Johar, n.d.) and the fact that the construction industry remains the biggest global polluter after agriculture (Circle Economy and ABN AMRO, 2017). In architecture, 
sustainability can be viewed by developers both as a costly 'nice to have' and a contemptible hippy concept. In addition, the focus on the planet - a nebulous and often conflicted space - can do little to endear developers. Since the Rio conference in 1992, the concept of sustainability has become an established philosophy for governments worldwide to promote a more balanced social, environmental and economic (less extractive) human development (United Nations, 1992). However, improvements are needed to adapt and apply the philosophy in the challenging context in which we live today. To support the internationally agreed UN Sustainable Development Goals (United Nations, 2015) new and holistic models are required to assist co-production of scalable solutions for communities. These are frameworks - consisting of focused policies and local structures - that can be open and agile enough to generate ownership amongst a diverse group of stakeholders, evoking alternative pathways to urban development. Hopwood et al's (2005) paper provides a comprehensive reading of different understandings of sustainable development; in particular, it concludes that, "it provides a useful framework" which needs to "be based on appreciation of the close links between environment and society with feedback loops both ways", and that "social and environmental equity are fundamental ideas" (Hopwood et al, 2005:49). Missimer et al (2017) provide an updated understanding of what this means for strategic approaches to social sustainability, building on a discourse put forward by Robinson's (2004) paper on sustainable development.

A networked place-based approach (Monbiot, 2017) is novel in the way that it makes best use out of pools of common resource, knowledge and experience - and uses advancements in technology to channel knowledge exchange, distributed decision-making and governance (Kitchin 2014; 2018). In an empirical investigation of social innovation initiatives for sustainable urban development, Angelidou and Psaltoglou (2017:115) found the link between social innovation and sustainable development to be "very pronounced" owing to the challenges that contemporary urban settlements face and their position as "places where urban futures and the knowledge and innovation economy come together". Their investigation puts social innovation for sustainable urban development in two "clusters of literature", one concerned with "the role of citizens and their communities" and a second one concerned with "socio-technical transitions, focusing on the process and involved actors in social innovation" (Angelidou and Psaltoglou, 2017:115). They identified four types of citizen profiles in the sustainability discourse: the 'citizen sensor', the 'sharing citizen', 'the collaborative citizen' and 'the entrepreneurial citizen", were citizens can have dual or multiple roles "depending on the situation" (Angelidou and Psaltoglou, 2017:122).

The global financial crisis in $\mathbf{2 0 0 8}$ has acted as a driver of the relentless pace of technological innovation were the low costs of computing hardware has given rise to ubiquitous technology - with sensors and data collectors embedded across our public realm and private spaces creating an 'Internet of Things' (Greenfield, 2017; Ash et al, 2018; Kitchin, 2014; 2018). The increased capabilities to collect data have given rise to the era of Big Data (Kitchin, 2014) where complex data sets, comprising information modelled from new data sources, converge to produce a sophisticated real-time evidence base for 
decision-making (Kitchin, 2018). Increasingly, local governments are building city dashboard software or enterprise platforms that can use these data to build a robust evidence base for informing policy interventions and decision-making. Technology-led, big-data approaches to city management often fall under the domain of the smart city, a paradigm that has emerged in the past decade as an umbrella term for strategies that propose technology as integral to addressing the intractable problems of society (Greenfield, 2017; Hollands, 2008). As criticism of the smart city and of neoliberal approaches to social innovation more generally gain traction, it is important that research closely examines the role of the government in facilitating participation in planning. This includes the development of technology, systems and applications - open to manipulation - under the guise of providing platforms for 'smart' democracy.

Contemporary approaches to sustainable urban planning and design recognise the importance of developing place-based frameworks for development that take holistic social, economic and environmental factors into consideration. A framework, in the context of this paper, encompasses the policy and the structures that may enable sustainable community (renewal) transformation to take place. Such frameworks are needed because for too long many in the built environment professions - motivated by questionable ethical positions - have worked too closely with commercial actors, facilitating unsustainable development that has exacerbated inequality and encouraged rampant gentrification (Hollands, 2008). In recent years, this close relationship between architects and developers in particular has left many questioning the role of the contemporary architect and their value to modern society (Wainwright, 2014). Conversely, there is little collaboration outside of the design team and even less with communities where development is proposed, the eventual users of these spaces (Vasuvedan, 2015). Over the decades, participatory design in architecture has often been tokenistic or occurring too late in the design phase to affect decisions that impact communities (Oliver and Pearl, 2018). The planning system can be bureaucratic and burdensome and requires multiple actors working in unison - under welldefined frameworks - to deliver the type of sustainable development that promotes inclusive growth. Reasons for this are layers of planning rules and behaviours that have been added to and renovated to accommodate political ideologies of short-term governments (Greenfield, 2017). Authorities and local governments have often produced plans or strategies that focus exclusively on economic growth as a pathway out of inequity, working towards KPIs and quantitative outcomes that mask multiple indices of social deprivation and structural poverty that cause communities to decline and require regeneration (Greenfield, 2017). Planners are destined to repeat the mistakes of the past slum clearances that produce peripheral ghettos - without a set of new tools and processes that can help them work towards new collective social outcomes, common across a whole ecosystem of community agencies.

The impacts of globalisation - and the inequitable relationships between richer and poorer actors - are manifest in environmental, economic and social shocks experienced by communities worldwide. This investigation, which takes a global perspective, along with 
literature review, follows an ethnographic action research approach, engaging communities in participatory dialogue to build up a deeper understanding of the context for resilience. Walker et al's (2004:n.p.) definition of resilience as "the capacity of a system to absorb disturbance and reorganize while undergoing change so as to still retain essentially the same function, structure, identity and feedbacks" and expanded by Folke (2006) to include "adaptability" and "transformability" (Folke, 2006:262), is adopted in this paper.

This paper concentrates on the frameworks phase and highlights some tools used by public and private sector in the United Kingdom that aim to enable participatory planning such as the Place Standard and BREEAM Communities. The paper presents a case study on the Aktivniy Grazhdanin, an online participatory tool used in Moscow, as an example of the attempt to use such tools with a similar aim. Characteristics and some limitations of all three approaches are critically presented. Action research was a means for developing the case study in Moscow, the basis of which was informed by criteria identified by examples form the literature review. Included from the literature review, the Place Standard, a conversational tool, and BREEAM- Communities Assessment, a paper based assessment tool, are examples of inclusive approaches to city planning. When viewed alongside the Moscow case, the failures of a more technological - but perceived to be less open approach begin to surface. Engagement in real-life means that relationships are developed among stakeholders and organisation through the act of achieving a consensus in a participatory dialogue. Findings from action research share an ontological language with the "Social Grid Model" as developed by Beckert (2010) and extended by von Jacobi et al (2017). Similarly, the Social Grid Model recognises the interconnections between networks, cognitive frames and institutions (Beckert, 2010; von Jacobi et al, 2017). Action research methods used in Moscow are described in more detail within the case study.

\section{Tools and mechanisms used in place-based frameworks}

\section{Scotland's Place Standard Engagement Tool}

UN Sustainable Development Goals (SDGs) (United Nations, 2015) are translated into overarching national policies used by local agencies to develop specific targeted and contextual local development strategies. In the case of Scotland, the UN SDGs have informed Scotland's SDGs (Scottish Council for Voluntary Organisations, 2018), expressed as vision statements in Scotland's National Outcomes (Scottish Government, 2018a) and Scotland's Third National Planning Framework (Scottish Government, 2014). These policies are supported by legislation under the Scottish Government's Public Engagement and Consultation, Community Empowerment Scotland Act (2015) (Scottish Government, 2015) and set against National Standards for Community Engagement (Scottish Government, 2016) which mandate a level of community engagement and participation on development projects. In response, tools such as the Place Standard have emerged as a method to engage citizens to assess their settlements and prioritise local goals aligned to overarching global and national sustainable development policies. 
The Place Standard, a tool which was developed with planners and architects in Scotland, "lets communities, public agencies, voluntary groups and others find those aspects of a place that need to be targeted to improve people's health, wellbeing and quality of life"; provides "a simple framework to structure conversations about place" and takes a longterm view of sustainability, encompassing a number of domains - including local economy, public transport, and housing - allowing distinct and separate organisations to work together productively (Place Standard, n.d.). Along with economic and spatial aspects, it has been designed to consider social aspects - health, welfare, work and community - by measuring, for example, whether citizens feel empowered in local decision-making. The tool prompts discussion among stakeholders, helping to identify assets and resources within a community as well as challenges and areas for improvement. The Place Standard is used primarily as a sustainable development assessment tool that allows communities to take a zoomed-out holistic look at place and identify priorities for social innovation, based on a clear and measurable set of indicators. The tool is used "to assess the quality of a place" undergoing transition and planning for change, or for an established community. It is a simple tool that consists of 14 themes covering both the physical and social aspects of a place, allowing participants to identify potentiality, and support design and delivery. In this way, the Place Standard works as a tool with which to define barriers and opportunities for social improvement that could be brought about through specific projects or strategic interventions.

In Scotland, communities who are seeking to embark on a journey of regeneration or physical improvement are encouraged to use the Place Standard, often with the support of Planning Aid Scotland through workshops and charrettes (Planning Aid Scotland, n.d.). By using the tool to interrogate project outcomes, development proposals are ideally more balanced, achieve community buy-in and generate ownership among stakeholders. Scotland's SDGs are more precisely defined at a local level through the tool, resulting in a local development plan (LDP) - framework - once shared outcomes have been agreed in terms of a development approach. In this way, the Place Standard tool is part of a process of sustainability and not an end in itself. It is a way to develop priorities for places, a value system and consensus around a collective strategy for improvement (Place Standard, n.d.). The tool helps community ecosystem comprised of multiple actors to collaborate, plan for and measure social impact. The tool is now being used by the National Health Service (NHS) in Scotland as a methodology to scope, measure and evaluate policy interventions in health (Scottish Government and Architecture and Design Scotland, 2017). By focusing on themes of health and well-being in a place - themes which are important to all stakeholders - the Place Standard, as a tool, facilitates discussions on a local level about those goals. As a way to build common bonds and understanding between citizens and groups, health and wellbeing are a powerful proxy. An overarching strategy to improve outcomes for health can impact design decisions for both the public realm and public services and help translate high-level policy ambitions into measurable compliances in a brief or design document. A 
city that proposes an overarching policy based around wellbeing also encourages the development solutions that give advantage to wider innovation in healthcare or technology, often bringing in solutions from other sectors that have never been applied to the built environment. It can be said the Place Standard is a comprehensive tool for engaging communities in decision-making about local priorities for social improvement. The Place Standard is used comprehensively by Planning Aid Scotland (PAS) as a bottom-up engagement mechanism in their work with communities regarding local planning issues and extensively in workshops and public charrettes (Planning Aid Scotland, n.d.).

The Place Standard has been rolled out across a number of development projects in Scotland since 2015, and has been closely evaluated during the first years by Scottish Government (Scottish Government and Architecture and Design Scotland, 2017). NHS Scotland are working with Architecture and Design Scotland and Scottish Government on the implementation of the Place Standard, alongside key partners including the Improvement Service and Glasgow City Council. A report in 2017 listed 65 separate instances of Place Standard being used across Scotland between December 2015 and February 2017 - reaching over 11,000 citizens in Scotland, across 22 local authorities (Scottish Government and Architecture and Design Scotland, 2017). The Place Standard has been applied in many different contexts and a variety of ways. It has been used most commonly to facilitate community engagement to inform local planning (e.g. development of locality plans) or strategic planning (e.g. master-planning or to inform a council's strategic plans).

While the Place Standard was developed in albeit a top-down-way, it opens a line of dialogue for bottom-up engagement. While open to abuse in practice, it has succeeded as a tool that promotes collaboration among quite disparate stakeholder groups - often with quite distinct positions - allowing them prioritise shared (and measurable) outcomes for transformation of place. Overall the tool has been well-received as an aid in aligning ambitions within a community ecosystem, particularly within the context of community engagement, owing to its universality and ease of use. In particular the Place Standard diagram was "perceived to be a powerful representation of place that could be used to direct actions" (Scottish Government and Architecture and Design Scotland, 2017:5). The report found that aligning the engagement process to strategic decision-making achieved most buy-in from stakeholders, helping them to arrive at a shared consensus (Scottish Government and Architecture and Design Scotland, 2017). This said, however, as a tool with which to organise strategic actions, it requires further refinement. Managing and organising respondents' data can be resource intensive and ambiguity arises when using the tool over roles and responsibilities for individuals and organisations in taking forward actions (Scottish Government and Architecture and Design Scotland, 2017). It is important to emphasise that Architecture and Design Scotland see the use of the Place Standard as a process, and that qualitative insights obtained through the use of the tool are important to identifying priorities (Scottish Government and Architecture and Design Scotland, 2017). A significant challenge identified through the Scottish Government evaluation was to ensure community 
engagement is representative of the whole population in a place and that future efforts seek to support engagement with those who are most marginalised and under-represented as a precursor for reducing inequality and promoting inclusive growth (Scottish Government and Architecture and Design Scotland, 2017). However, it must be stressed that the Place Standard is in itself a prototype and should be refined in an open co-development process with communities and user groups. Viewed alongside digital engagement tools (that are appraised later in this paper) the value of the Place Standard is how it facilitates face-to-face conversations.

\section{BREEAM-Communities Assessment Tool}

The Building Research Establishment (BRE) has developed BREEAM-Communities (BREEAMC) as a development assessment tool to help developers and private sector stakeholders to take sustainability concerns into account. It contains a compulsory consultation component in order to ensure the "needs, ideas and knowledge" of communities are taken into account during the detailed planning stage of a development (BRE, 2012). Community participation in BREEAM-C is required to certify the master planning process (Oliver and Pearl, 2018; BRE, 2012). The tool defines a number of domains and sets of indicators in order to assess the quality of design in terms of the social, economic and environmental impacts of development on a community. BREEAM-C, however, is primarily envisaged to help a design team engage with sustainability issues in the early design phase of a development project.

Oliver and Pearl (2018) looked at how the BREEAM-C tool was used by the developer of a large mixed-use new build project at Masthusen in the Swedish city of Malmö, focusing on its role in facilitating community consultation and participation. The study found the tool to be limited, "as a certification tool used solely by the developer, as opposed to a tool that could bring together the City of Malmö, community groups and the developer in a synergistic project" meaning that it was "limited to focusing on achieving sustainability outcomes within the boundaries of its site" (Oliver and Pearl, 2018:520). The study found that the tool, which focuses on product outcomes in the design process, "had a limited impact on empowering the immediate and surrounding communities and creating a synergistic, integrated design with its surroundings" (Oliver and Pearl, 2018:525). This was owing to the fact that tool was said to employ a "limited definition of community" and was employed too late in the process, meaning that consultation had no impact on the design (Oliver and Pearl, 2018:519). These observations point to the need to engage communities early in the design process - with community focused tools like the Place Standard, and to use these to facilitate a common vision or strategic mechanism for development across an ecosystem of competing stakeholder positions (developer, local government and community). This will help prevent engagement exercises that are no more than box-ticking for communities.

The Smart City Collaboration Mechanisms: Approaches and concerns 
The Smart City concept promotes cross-sector collaboration and partnership among stakeholders within a place to develop collective strategies for social innovation. The concept emerged in the early 2000s as a means for collecting data by using sensors, Information and Communication Technologies (ICT) and Internet of Things platforms that can inform better management of cities' services. It has been aggressively marketed by technology companies to cash-strapped city governments since the financial crash in 2008 (Greenfield, 2017; Kitchin, 2015; Kitchin et al, 2015; Hollands, 2008; 2015). While there is no agreed discrete definition among academics as to what the concept refers to exactly, there is a broad consensus that a smart city uses innovation in ICT as a means for achieving sustainable development, social innovation and improvement (Angelidou et al, 2017). While researchers agree that smart cities are defined by their use of innovation in technology, in practice it is not technology that makes a city smart, and many of innovative systems in use in urban management do little to improve quality of life or encourage sustainable development. Put simply by Kitchin (2014 1;2), Smart Cities are cities that "on the one hand, are increasingly composed of and monitored by pervasive and ubiquitous computing and, on the other, whose economy and governance are being driven by innovation, creativity and entrepreneurship enacted by smart people". Taking a systems-thinking approach to the Smart City, Caputo and Evangelista (2018:117) highlight that the Smart City depends on two main factors: "continuously updated Big Data and Smart Technologies" and "customer willingness to cooperate on their development", thus further emphasising the relationship between user (citizen) and technology in the Smart City paradigm.

At an international policy level, environmental sustainability concerns are integral to the concept of the Smart City (Angelidou et al, 2017; Angelidou and Psaltoglou, 2017; European Commission, n.d.) with many interventions focused on air quality, cleaner energy or transport solutions. The Smart City provides a lens for looking at the city as a system (Saviano et al, 2016) on which to model scenarios and policy interventions; prototype and test new solutions; and deliver new social infrastructure. Prevailing strategic mechanisms driving contemporary development interventions include those that focus on shared outcomes for change delivered by focusing on aspects that appeal to the whole eco-system within a place such as health and well-being, energy independence or technology-led change. Smart City technological solutions are adopted by many cities across the world as a mechanism for delivering community resilience through a focus on holistic social, economic and environmental outcomes (Angelidou et al, 2017; Colding and Barthel, 2017). Smart city technologies assist in acquiring big data to enable better informed evidence-based decisionmaking (Kitchin, 2014, 2018; Kitchin et al, 2015).

Cities have increasingly looked to the Smart City as a set of technologies that can support growth based on delivering greater efficiencies and better user experience for citizens among decreasing resources. City governments in Moscow (Moscow Mayor's Office, 2018a), London (Greater London Authority, n.d.), Dublin (Dublin City Council, 2016) and Barcelona (Ajuntament de Barcelona, n.d.) have all invested heavily in establishing Smart Cities programmes, labs and open data centres to assist in better city management and to 
curate the data that can inform future planning. Others such as Rio de Janeiro have initiated close partnerships with commercial partners - IBM in the case of Rio - around data management, management intelligence and to co-develop large scale city management enterprise software (Singer, 2012). Given its popularity among commercial leaders - namely large technology companies - and local governments focused on growth, the Smart City concept and suite of technologies can be viewed as a means for improving decision-making on management of cities' services, currently heavily focused on economic improvement.

While there has been much criticism of the smart city concept to date from futurists and technology commentators (Hollands, 2008, 2015; Greenfield, 2013; Townsend, 2013; Kitchin, 2014; Shelton et al, 2015), the built environment professions have been somewhat silent on what the Smart City concept means for an inclusive urban planning and design (Greenfield, 2017). One reason for this may be the lack of understanding within the sector around specific technology, innovation and its application. Architecture in particular can take a reactionary rather than objective view of intrusions into the sanctuary of the profession from new technologies and professions, evident from the ARB actions to protect the title of architect from software developers and enterprise architects in the not so distant past (Stott, 2013). Ironically, the division between the practice of designing for digital environments and for traditional built environments is increasingly less obvious (Greenfield, 2017) as user experience, software architecture and traditional architecture collide through the spatial application of artificial intelligence. The traditionally agile processes of software architecture development - building cheap and easy prototypes and testing them with user communities - present a new approach to participatory design that is genuinely impactful.

Mounting criticism of the smart city suggests that it lacks robustness, fails to deliver as a place-based framework for technology-enabled balanced and inclusive growth. Commentators such as Morozov and Bria (2018) join Greenfield $(2013,2017)$ and others who note how the paradigm is often used to further the neoliberal agendas of cashstrapped governments and their service providers. This criticism is increasingly levelled at social innovation practice in urban governance more generally - with the involvement of non-state actors in promoting small-government - under the guise of developing power to the grassroots (Massey and Johnston-Miller, 2014). In the paper "Critical interventions into the corporate smart city" Hollands (2015) expands on his earlier paper (Hollands, 2008), which first raised these concerns, and highlights the dangers of seeing technology as a panacea to all ill-gotten urban problems. Hollands (2015) refers to the work of Harvey (1989) and asks why the Smart City that is being promoted "can only be effectively delivered through a corporate vision of smartness, in conjunction with an entrepreneurial form of urban governance", shining light on the absence in urban sociology of "an alternative to the neo-liberal city, smart or otherwise" (Hollands, 2015:62). Echoing Hoornweg et al (2011), Hollands (2015: 63) reminds how "really smart urbanism needs to start with the city itself and its attendant social problems, rather than looking immediately to smart technology" and that this proposition will require both new tools and new rules, "new participatory 
urban technologies, greater social and economic inclusion". Hollands (2015:63) refers to Harvey (2012) and highlights the need for a "substantial shift in power from corporate business and entrepreneurial city leaders to ordinary people and communities".

The concept continues to be a significant means for informing better urban management and development, with research indicating about 355 smart city projects in 221 cities worldwide (Navigant Research, 2018) and figures from the European Commission suggesting 240 smart cities with populations over 100,000 (Euractiv, 2017). While ambitions remain high, concerns are mounting. Kitchin (2014) identifies five main concerns, particularly over the politics of data collection and data use; technocratic city governance and development; procurement and investment in technology and infrastructure; technological performance and security, and how the city is viewed as a system. Looking at the data concerns, Kitchin rightly states that "data within smart city initiatives are portrayed as being benign and lacking in political ideology" and questions whether the data or "algorithms used to process these data are neutral" (Kitchin 2014, 79:8) and if "data are infected by social privilege and social values" (Kitchin 2014, 79:9). On the notion of technocratic city governance, we are reminded that technology on its own is not going to solve "the deep-rooted structural problems in cities as they do not address their root causes" (Kitchin 2014, 79:9), but need to be "complemented with a range of other instruments... that are sensitive to the diverse ways in which cities are structured and function" (Kitchin 2014, 79:10). In terms of procurement, Kitchin refers to Shaffers et al. (2011:437) who note that "smart city solutions are currently more vendor push than city government pull", which begs the questions whether solutions that are being developed arise in response to a genuine social need, and whether systems will become quickly redundant as Hill (2013:n.p.) noted that "city fabric changes slowly yet technology changes rapidly". Kitchin (2014) refers to Townsend's (2013) well-presented concerns around the quality and performance of smart technology, alerting that "if we don't think critically now about the technology we put in place for the next century of cities, we can only look forward to all the unpleasant surprises they hold in store for us" (Townsend, 2013:n.p.). Kitchin (2014:12) states that "without regulated oversight... there is likely to be significant resistance and push back against real-time analytics by citizens". He sees engagement and participation with stakeholders as a way to counteract the emergence of a "panoptic city" and highlights that "without critical interrogations the smart cities of the future will likely reflect narrow corporate and state visions, rather than the desires of wider society" (Kitchin 2014:12).

Angelidou and Psaltoglou's (2017) comprehensive study presents the basic critical arguments regarding smart cities, by way of analysing nine individual smart city case studies, and comes to similar conclusions as Kitchin. The study identified shortcomings originating from contextual factors such as the broader political discourse of a place and others originating from the strategy itself (Angelidou et al, 2017). Angelidou et al (2017:80) found that corporate smart city visions are "increasingly driven by business imperatives", often misaligned with citizens' priorities - facing opposition from the local population in the 
case of Barcelona and Songdo (Angelidou et al, 2017; March and Ribera-Fumaz, 2016). Looking to research from Luque-Ayala and Marvin (2015), Angelidou et al (2017:80) found that corporate initiatives "fail to develop the capacity of a city's people to actually learn and deeply engage in the smart city discourse" (Angelidou et al, 2017:80) and that "citizen uptake and stakeholder resonance is critical... as citizens need not only be informed, but actively engaged in the co-design of the smart city solution" (Angelidou et al, 2017:88). The study points to other barriers to implementation arising from failure to attract adequate state support or poor strategic planning.

A deep and iterative literature review, in particular comprehensive studies by Kitchin (2014) and Angelidou \& Psaltoglou (2017) identified the important themes of ownership, governance and participation - which became the basis for probing conversations with citizens in Moscow. Viewing the criticisms by Kitchin (2014) and Angelidou et al (2017) alongside those of other academics across the literature review, the main questions that persist regarding the Smart City concern relationships between stakeholders - public, private and community actors in the pursuit of what Kitchin (2014) refers to as 'smart urbanism' that includes:

- Ownership - Who owns the (Big) data, proprietary software, innovation and strategy within the ecosystem?

- Governance - What roles, responsibilities, process and protocols are in place to facilitate collaboration and partnership?

- Participation - What is the quality of public engagement and how does it improve democratic decision making (around sustainable urban development)?

More detailed research is required to understand the nuances of a participatory dialogue with stakeholders around (smart) city development, which takes an in-depth look at the collaborative behaviours taking place within a sustainable and iterative urban design process. This should include analysis to understand what agile and iterative co-design processes - working closely with user communities - can be ported from the development of technical architecture to the practice of built architecture and urban design. This will mean looking outside of traditional domains to areas of technology and lean process management that view innovation "as an open paradigm predominantly focused on a user-centric approach that involves citizens and civil society (i.e. the customers) in smart project in terms of a technologically driven climate and external sources of knowledge" (Dezi et al, 2018:1248). By placing faith in new technology as panacea for sustainable urban development, the 'smart city' is at risk of not recognising the repetition of past mistakes, but embedding the lack of flexibility in the planning system into the planning algorithms of the future, producing a glitchy and inflexible city that performs on behalf of a narrow set of stakeholders (Townsend, 2013). This risk is compounded by the limits of the current planning system which often focuses narrowly on individual planning applications as opposed to marrying common goals and achievable outcomes across a place. 
What is required to offset these challenges is an open and participatory approach to planning, stewarded by a collaborative framework, that allows multiple stakeholders to be included and for complementary change narratives to emerge (Horgan and Dimitrijević, 2018), often facilitated through information and communications technology (Caputo and Evangelista, 2018). Participatory design as a concept in architecture and planning is not new in itself, yet genuine multi-agency collaboration within a place or locality, which can be difficult and complicated - is often forsaken in favour of box-ticking exercises at the end of a design phase of a development project (Oliver and Pearl, 2017). In Scotland however, Planning Action for Scotland (PAS) and the Royal Town Planning Institute (RTPI) have been among those pushing for change, which has come in the form of the Planning Bill (2018) (Scottish Government, 2018b) that mandates engagement with stakeholders through community councils and workshops. When used to facilitate open dialogue, tools such as the Place Standard can help communities better contribute to the development of strategic mechanisms like that of the 'Smart City', and in turn can provide the basis of a framework for multi-stakeholder place-based collaboration. The above questions have been used in the case study presented below, which looks at the 'Active Citizen' platform developed by Moscow's Smart City team.

\section{Case study: Aktivniy Grazhdanin and decision-making in Moscow, Russian Federation}

The use of Smart City technologies in Moscow provides a case study on an information-led mechanism for informing decisions on sustainable development and enabling citizens' participation in decision-making in city management and potentially in urban planning and design. This investigation was carried out primarily through action research which has been refined over recent decades as an important research method to understand interconnections between policy and practice, and to gather insights from real-life experiences of stakeholders and communities (Reason and Bradbury, 2001). In this case, research consisted of an embedded ethnographic investigation over a one-month period that entailed meeting and living with residents in the city of Moscow over the summer of 2018. The research was conducted through semi-structured, face-to-face interviews with citizens and more formal interviews with identified stakeholders from the Smart City team. Initial contact was made with citizens subscribed to the "Москвичи против сноса» or 'Muscovites against demolition' group of activists on Facebook to arrange interviews. Interview questions were taken from an initial set drafted prior to travel to Moscow and iterated during the action research phase to focus on emerging themes and aspects of ownership, governance and participation.

In total, seven face-to-face interviews were conducted with citizens in Moscow, engaging with a further five in detailed online conversations and a further seven through interaction via social media. A number of limitations impacted the research, including the desire for most of citizens canvassed to remain anonymous - meaning that specific details around neighbourhoods and displacement are not revealed. Respondents came from a wide section of society including young professionals, public sector workers, well-informed technologists and retired older people. The interview questions explored how well a community was able to participate in decision-making and whether they had adequate tools "to effect change" in 
the context of planning and the built environment. A longer interview was conducted with a leader of Moscow's Smart City team, with a view to organise subsequent discussions with city government officials. Meetings with colleagues in local government never materialised. While the climate of the World Cup, which was taking place at the time of field research in Moscow, facilitated a more open dialogue with citizens then usually, the underlying political climate in Russia meant that a deeper and more verifiable methods of both qualitative and quantitative data collection was difficult.

The study focuses primarily on Aktivniy Grazhdanin (AG, Active Citizen) a tool developed by the Moscow Smart City team in order to engage citizens around urban development proposals and change in Moscow, as part of strategies for technology led growth. The platform, which is now set to be rolled out across the whole Russian Federation (Bobilev, 2018), facilitates citizen oversight and participation in planning decisions. It primarily focuses on decision making on issues relating to the upgrade of the public realm and public spaces, as well as getting feedback on local government proposals, city strategies and development policies. Developed to offset a top-down approach to city planning, it purports that over 2,000,000 Active citizens have participated, representing up to $20 \%$ of Moscow citizens (Holder, 2017). The city of Moscow is currently undergoing a large-scale programme of renovatsiya - or renovation - where poorly performing buildings are due to be demolished in favour of improved housing projects to be built on the periphery of the city (Alonso, 2018). The theme of renovation is of great concern to a great many of citizens in Moscow, where private ownership of apartments is high owing to the change in economic system during the 1990s (Krasheninnokov, 2003). AG has been used (alongside other engagement tools) to gauge citizens' opinions on development, although it has no basis in law. While respondents were interviewed about the platform generally, the focus of the investigation was on decision-making on renovation in particular, which is set to affect more than two million citizens in Moscow over the next fifteen years (Holder, 2017).

\section{Ownership}

While the majority of voting on AG takes place on the web platform, or mobile web application, there is also the possibility for informed citizens to vote in person at a Moy Dokumenti (My Documents) one-stop-shop for delivering local public services. This allows for participation from the whole citizenry, provided that they are informed through channels such as Metro advertising and public information exercises. High levels of usage of the AG platform are associated with functionality around the "Our City" urban repair and development scheme (Murawski, 2018), part of which allows citizens to submit complaints relating to urban environmental issues such as potholes and dumping (similar to MySociety's Fix My Street, developed for London and other cities). A consistent feedback loop, where issues are responded to by the local government within a fixed time period of five days, results in a high rate of satisfaction. Two hundred streets have been improved or redeveloped through this function in addition to repairs and resolution of other issues.

Detailed citizens' profiles allow for geo-targeted polling, particularly around themes relating to renovation, where two thirds of citizens need to agree to demolition of a particular 
apartment block, according to the programme. This however has no basis in Russian law, which requires full consent of occupants before an apartment block is selected for demolition (Leslie and Charley 2017).

A perceived lack of ownership is evident in cases where if no occupants of a block vote, that building is assumed to be compliant with demolition. In both online research and in interviews, respondents referred to the platform as "Fiktivniy Grazhdanin" (or fictitious citizen) owing to the lack of transparency around where ideas come from, the design of survey questions and the breakdown of voting results. In many cases there is no limit to the amount of times an individual can cast a vote on a particular issue. In conversation with the development team, it appears that the majority of ideas on AG come from the local government system, while there is a separate ideas platform open for citizens with ideas for the city, What Moscow Wants (Moscow Mayor's Office, 2018b). Interviewees referred to a case where voting on one issue (the renaming of a metro station) recorded ten votes every ten minutes consistently through the night which may suggest an automated programme was used to cast votes. In the context of voting around renovation or demolition (and displacement), however, further information is required to identify voters. Yet the perception that there is no real ownership over decision making on renovation in Moscow was common, with many seeing AG as a way to provide a veneer of compliance.

\section{Governance}

An interview with Moscow's Smart City team (a function of the Moscow Mayor's office) revealed that local governance admittedly functions in a very top-down way. This team, however, emerged from a need to centralise information and communications technology systems so as to reduce duplication, incoherent procurement and public spending, deliver greater efficiency and reduce bureaucracy. This has allowed the city to take a holistic view for planning for both public services and infrastructure. Ideas often come from the market, while specific government departments act as gatekeepers for ideas that are then submitted to the team. Good ideas then undergo a proof of concept phase, before being presented to the mayor and subsequently included on the AG platform, or not. During development of a large urban park (Zaryade), on a vacant site adjacent the Kremlin, citizens were polled on design concepts and spatial functions. In interviews, however, respondents complained that it felt like AG was being used to facilitate already decided procurement decisions, for instance around the removal and planting of trees in the city, or almost continuous pavement installation. Many felt that, while not overtly facilitating corruption, AG represented a smokescreen of perceived openness around decision-making that was in fact only simulated. Notably, the development company behind the AG system is said to have been behind the platform designed to encourage support for Mayor Sobyanin's recent re-election in September 2018 (Meduza, 2018).

With regard to renovation in particular, the ambiguity in Russian law around public ownership of property, owing to the change in economic system presents unique difficulties. Effectively, private ownership of property in the case of mass housing extends 
only to the space of an apartment, meaning that the building fabric, envelope and environs remain effectively in state ownership (Semiletova, 2011). This allows for a situation where government, banks and development agencies keep a tight control over urban development and planning decisions. While a process does exist where citizens can achieve ownership of the (public) space which their building occupies, this involves a costly process where all apartment owners must agree to purchase the land together, employ a consultant who prepares a plan that must be accepted by the city authorities and included in the general plan for the city of Moscow (UNECE, 2004). This option is open to a truly limited number of citizens or communities (primarily due to the costs involved). In terms of the ability of citizens to influence wider urban development decisions affecting their local neighbourhood and the city of Moscow more generally, respondents felt that questions were designed in such a way as to encourage participants to select answers that would positively resonate with existing plans of the local government. A decision to establish an open-air museum at a site on Khokhlovskaya Square (Moscow Mayor's Office, 2018c) was cited as an example of this.

\section{Participation}

Additional systems provided by the Moscow local government to allow citizens to suggest proposals or ideas for the city are not effectively connected into AG. Respondents complained that invariably the type of ideas to be voted on the AG platform were of little consequence to the actual urban development in the city, and participation was often open to decisions that had very little impact. Examples cited included decisions around the colour of seats in the Luzhniki stadium refurbishment, or the choice of tiles in an improvement of the urban realm. Respondents were highly sceptical that alongside an option of "Yes" or "No", an option to "leave it to the experts" was also included, which was often the highest voted outcome in the case of important public realm decisions. This left citizens to feel that real participation in decision making was not possible around these issues. Citizens can earn points for participation in decision-making via AG platform (Moscow Mayor's Office, 2017) which can be exchanged for Metro credit and other prizes, and incentivises participation, in particular of those from lower economic backgrounds, increasing the potential for manipulation.

While the AG platform allows for geo-targeted polling of citizens around renovation or demolition, this is seen as designed to simulate a perceived participation, where truly open and transparent decision-making was lacking. The wider socio-economic context in Moscow, which remains the centre of economic activity in Russia and offers a significantly higher quality of life to citizens, is an important consideration when looking at the context of public participation and engagement. Respondents noted the importance of the construction industry, in a difficult economic context of sanctions, as a factor in the urban development processes. This is perhaps evident in cases where buildings in good condition, occupying high value land are chosen for demolition, and others in a far worse condition in undesirable parts of the city are ignored. While there are clear advantages to urban 
development in engaging with citizens through online systems such as AG, these should not replace traditional forms of face-to-face engagement. This can be particularly difficult in a Russia however, where policy exists to prohibit certain forms of public organisation or protest. More research needs to be done by comparing hard data with decision-making outcomes to truly assess the value - transparency and openness - of the Aktivniy Grazhdanin platform.

\section{Conclusions}

Taking discussions with citizens and local government stakeholders on Aktivniy Grazhdanin into account, alongside the literature review into Smart City technology-led engagement more widely, it is clear that major concerns exist around ownership, governance and participation. While technology provides cheap and effective ways to engage citizens around issues that have little material impact on their day to day lives and future resilience, when decision-making is required on large issues such as renovation or displacement, there is no substitute for offline face-to-face engagement in a real-world context. In Scotland, this ambition is emphasised in the Scottish Government's commitments to public engagement through the planning acts and charrette programme. In the context of Moscow, which is considered to be a world leader in facilitating urban development and socio-economic resilience for citizens through its Smart City programme (facilitated through Aktivniy Grazhdanin), the use of technology to sanction neo-liberal planning and construction processes is of great concern. Deeper ethnographic studies are required to better understand the impact and outcomes for citizens under the process of renovations and demolition. In particular, this should concentrate on the risks to maintain community resilience (alongside the ethics around acquiring private assets by displacement), and where truly socially innovative tools or actions could support citizens.

This paper forms part of a comprehensive and global study, and comprises a number of case studies, selected for their socially innovative qualities, and investigated along a common pathway of deeply ethnographic action research. Subsequent research builds on tools and technologies for developing place-based social innovation frameworks identified in this study with further research pertaining to environmental outcomes, conducted in parallel.

\section{References}

1. Ajuntament de Barcelona. (n.d.) Barcelona Digital City. https://ajuntament.barcelona.cat/digital/en/ Accessed 20 June 2018.

2. Alonso, P. I. (2018). From Mass-Production to Mass-Destruction. ARQ (Santiago), 98, 92-105. http://dx.doi.org/10.4067/S0717-69962018000100092.

3. Angelidou, M. \& Psaltoglou, A. (2017). An empirical investigation of social innovation initiatives for sustainable urban development. Sustainable Cities and Society, 33, 113-125. DOI: 10.1016/j.scs.2017.05.016. 
4. Angelidou, M., Psaltoglou, A., Komninos, N., Kakderi, C., Tsarchopoulos, P. \& Panori, A. (2017). Enhancing sustainable urban development through smart city applications. Journal of Science and Technology Policy Management, (9)2, 144-169. https://doi.org/10.1108/JSTPM-05-2017-0016.

5. Ash, J., Kitchin, R., \& Leszczynski, A. (2018). Digital turn, digital geographies? Progress in Human Geography, 42(1), 25-43. https://doi.org/10.1177/0309132516664800.

6. Beckert, J. (2010). How do fields change? The interrelations of institutions, networks, and cognition in the dynamics of markets. Organization Studies, 31(5), 605-627. DOI: https://doi.org/10.1177\%2F0170840610372184

7. Bobilev, R. (2018) Проект «Активный гражданин» запустят во всех регионах России. (In Russian) 25 June. Available from: https://daily.afisha.ru/news/17899-proekt-aktivnyy-grazhdanin-zapustyat-vovseh-regionah-rossii/ Accessed 9 November 2018.

8. Bria, F., Sestini, F., Gasco, M., Baeck, P., Halpin, H., Almirall, E., \& Kresin, F. (2015). Growing a digital social innovation ecosystem for Europe: DSI Final Report. Brussels: European Commission. DOI: 10.2759/448169.

9. Building Research Establishment (2012). BREEAM Communities: Technical Manual SD202 1.2: 2012. https://www.breeam.com/communitiesmanual/ Accessed 20 June 2018.

10. Caulier-Grice, J., Davies, A., Patrick, R., \& Norman, W. (2012). Defining social innovation. A deliverable of the project: "The theoretical, empirical and policy foundations for building social innovation in Europe" (TEPSIE), European Commission-7th Framework Programme. Brussels: European Commission, DG Research.

11. Caputo, F. \& Evangelista, F. (2018). The role of information sharing and communication strategies for improving stakeholder engagement. In S.M. Riad Shams, D. Vrontis, Y. Weber \& E. Tsoukatos (Eds.), Business Models for Strategic Innovation: Cross-Functional Perspectives (pp. 51-69). Routledge.

12. Circle Economy \& ABN AMRO (2017). A Future-Proof Built Environment. https://www.circleeconomy.com/case/a-future-proof-built-environment/\#.W-tCLC2cbuQ / Accessed 20 June 2018.

13. Colding, J., \& Barthel, S. (2017). An urban ecology critique on the "Smart City" model. Journal of Cleaner Production, 164, 95-101. https://doi.org/10.1016/j.jclepro.2017.06.191.

14. Dezi, L., Pisano, P., Pironti, M. \& Papa, A. (2018). Unpacking open innovation neighborhoods: le milieu of the lean smart city. Management Decision, 56(6),1247-1270. https://doi.org/10.1108/MD-042017-0407.

15. Dublin City Council (2016). Smart Dublin. http://www.dublincity.ie/SmartDublin/ Accessed 20 June 2018.

16. Euractiv. (2017). How many smart cities are there in Europe?. https://www.euractiv.com/section/digital/infographic/how-many-smart-cities-are-there-in-europe/ Accessed 20 June 2018.

17. European Commission (n.d.). Smart cities: Cities using technological solutions to improve the management and efficiency of the urban environment. https://ec.europa.eu/info/eu-regional-andurban-development/topics/cities-and-urban-development/city-initiatives/smart-cities_en/ Accessed 20 June 2018.

18. Finger, M. (2018). Smart City - Hype and/or Reality. IGLUS Quarterly: Innovative Governance of Large Urban Systems, 4 (1), 2-6. http://iglus.org/wp-content/uploads/2018/07/IGLUS-Quarterly-Vol-4-Issue1.pdf/ Accessed 20 June 2018.

19. Folke, C. (2006). Resilience: The Emergence of a Perspective for Social-Ecological Systems Analyses. Global environmental change, 16(3), 253-267. DOI: https://doi.org/10.1016/j.gloenvcha.2006.04.002

20. Greater London Authority (n.d.). Smart London. https://www.london.gov.uk/what-we-do/businessand-economy/supporting-londons-sectors/smart-london/ Accessed 20 June 2018.

21. Greenfield, A. (2013). Against the smart city: This is Part I of The city is here for you to use. New York: Do projects. 
22. Greenfield, A. (2017). Radical Technologies: The Design of Everyday Life. London and New York: Verso Books.

23. Harvey, D. (1989). From Managerialism to Entrepreneurialism: The Transformation in Urban Governance in Late Capitalism, Geografiska Annaler: Series B, Human Geography, 71(1), 3-17. DOI: $10.2307 / 490503$.

24. Harvey, D. (2012). Rebel cities: From the Right to the City to the Urban Revolution. London and New York: Verso Books.

25. Hill, D. (2013). On the smart city: Or, a 'manifesto' for smart citizens instead. City of Sound. http://www.cityofsound.com/blog/2013/02/on-the-smart-city-a-call-for-smart-citizens-instead.html/ Accessed 20 June 2018.

26. Hollands, R. G. (2008). Will the real smart city please stand up? Intelligent, progressive or entrepreneurial? City, 12(3), 303-320. https://doi.org/10.1080/13604810802479126.

27. Hollands, R. G. (2015). Critical interventions into the corporate smart city. Cambridge Journal of Regions, Economy and Society, 8(1), 61-77. https://doi.org/10.1093/cjres/rsu011.

28. Holder, S. (2017). Can the Blockchain Tame Moscow's Wild Politics? CityLab. https://www.citylab.com/life/2017/12/can-the-blockchain-tame-moscows-wild-politics/547973/ Accessed 20 June 2018.

29. Hoornweg, D., Sugar, L. \& Trejos Gomez, C. L. (2011). Cities and greenhouse gas emissions: moving forward, Environment and Urbanization, 23(1), 207-227. DOI: 10.1177/0956247810392270.

30. Hopwood, B., Mellor, M., \& O'Brien, G. (2005). Sustainable development: mapping different approaches. Sustainable development, 13(1), 38-52. DOI: http://dx.doi.org/10.1002/sd.244

31. Horgan, D. \& Dimitrijević, B. (2018). Social innovation systems for building resilient communities. Urban Science, 2(1), 13. DOI:10.3390/urbansci2010013.

32. Jacobs, J. (1961). The Death and Life of Great American Cities. New York: Random House.

33. Johar, I. (n.d.) Societal Innovation \& Our Future Cities: The Case for a Social Contract for Innovation. Dark Matter Laboratories. https://provocations.darkmatterlabs.org/the-societal-contract-forinnovation-15593ae9a1d4/ Accessed 20 June 2018.

34. Johannessen, J. A. (2013). Innovation: a systemic perspective-developing a systemic innovation theory. Kybernetes, 42(8), 1195-1217. DOI: https://doi.org/10.1108/K-04-2013-0069

35. Kitchin, R. (2014). The real-time city? Big data and smart urbanism. GeoJournal, 79(1), 1-14. DOI: 10.1007/s10708-013-9516-8.

36. Kitchin, R. (2015). Making sense of smart cities: addressing present shortcomings. Cambridge Journal of Regions, Economy and Society, 8(1), 131-136. https://doi.org/10.1093/cjres/rsu027.

37. Kitchin, R. (2018). Disruptive 3D Geospatial Technologies for Planning and Managing Cities. International Journal of Urban and Regional Research, 41(1), 84-103. http://www.ijurr.org/spotlighton-overview/disruptive-technologies/disruptive-3d-geospatial-technologies/ Accessed 20 June 2018.

38. Kitchin, R., Lauriault, T. P. \& McArdle, G. (2015). Knowing and governing cities through urban indicators, city benchmarking and real-time dashboards. Regional Studies, Regional Science, 2(1), 6-28. DOI: 0.1080/21681376.2014.983149

39. Krasheninnokov, A. (2003). Understanding Slums: Case Studies for the Global Report on Human Settlements 2003, The case of Moscow, Russia. http://www.ucl.ac.uk/dpuprojects/Global_Report/pdfs/Moscow.pdf/ Accessed 20 June 2018.

40. Leslie, C. \& Charley, J. (2017). The wrecking ball swings at Moscow - a photo essay. The Guardian, 31 October. https://www.theguardian.com/cities/2017/oct/31/moscow-residents-vote-russiademolition-rehousing/Accessed 20 June 2018.

41. Luque-Ayala, A., \& Marvin, S. (2015). Developing a critical understanding of smart urbanism?. Urban Studies, 52(12), 2105-2116. DOI: https://doi.org/10.1177/0042098015577319

42. Manzini, E. (2014). Making Things Happen: Social Innovation and Design. Design Issues, 30(1), 57-66. DOI:10.1162/DESI_a_00248. 
43. March, H. \& Ribera-Fumaz, R. (2016). Smart contradictions: The politics of making Barcelona a Selfsufficient city. European Urban and Regional Studies, 23(4), 816-830. DOI: 0.1177/0969776414554488

44. Marcuse, P. (1998). Sustainability is not enough. Environment and Urbanization, 10(2), pp. 103-112. DOI: 10.1177/095624789801000201.

45. Massey, A., \& Johnston-Miller, K. (2016). Governance: public governance to social innovation?. Policy \& Politics, 44(4), 663-675. DOI: https://doi.org/10.1332/030557314X14042230109592

46. Meduza (2018). A software developer with big Moscow City Hall contracts is behind a 'social movement' to re-elect the mayor, 26 June. https://meduza.io/en/news/2018/06/26/a-softwaredeveloper-with-big-moscow-city-hall-contracts-is-behind-a-social-movement-to-re-elect-the-mayor/ Accessed 20 June 2018.

47. Missimer, M., Robèrt, K. H., \& Broman, G. (2017). A strategic approach to social sustainability-Part 2: a principle-based definition. Journal of cleaner production, 140, 42-52. DOI: https://doi.org/10.1016/j.jclepro.2016.04.059

48. Monbiot, G. (2017). How do we get out of this mess? The Guardian, 9 September. https://www.theguardian.com/books/2017/sep/09/george-monbiot-how-de-we-get-out-of-this-mess/ Accessed 20 June 2018.

49. Morozov, E., \& Bria, F. (2018). Rethinking the smart city: Democratizing urban technology. Rosa Luxemburg Stiftung: New York, NY, USA. http://www.rosalux-nyc.org/wpcontent/files_mf/morozovandbria_eng_final55.pdf Accessed 03 February 2019

50. Moscow Mayor's Office (2017). Governing Moscow: How citizens can influence the city's development, 25 September. https://www.mos.ru/en/news/item/29558073/?onsite_molding=2/ Accessed 20 June 2018.

51. Moscow's Mayor's Office (2018a). Merging Reality and VR: How Does a Smart City Work?: https://www.mos.ru/en/city/projects/smartcity/ Accessed 20 June 2018.

52. Moscow Mayor's Office (2018b). What Moscow Wants. http://moscowidea.ru/ Accessed 20 June 2018.

53. Moscow Mayor's Office (2018c). You decide! or How active citizens are changing Moscow, 17 February. https://www.mos.ru/en/news/item/34881073/ Accessed 20 June 2018.

54. Mulgan, G. (2006). The process of social innovation. Innovations: technology, governance, globalization, 1(2), 145-162. DOI: https://doi.org/10.1162/itgg.2006.1.2.145

55. Mulgan, G., Tucker, S., Ali, R., \& Sanders, B. (2007). Social innovation: what it is, why it matters and how it can be accelerated.

56. Murawski, M. (2018). My Street: Moscow is Getting a Makeover, and the Rest of Russia is Next. The Calvert Journal. http://www.calvertjournal.com/features/show/10054/beyond-the-game-my-streetmoscow-regeneration-urbanism/ Accessed 20 June 2018.

57. Murray, R., Caulier-Grice, J. \& Mulgan, G. (2010). The open book of social innovation. London: Young Foundation and NESTA. https://youngfoundation.org/wp-content/uploads/2012/10/The-Open-Bookof-Social-Innovationg.pdf/ Accessed 20 June 2018.

58. Navigant Research (2018) Navigant Research Smart City Tracker 1Q18 - Global Smart City Projects by World Region, Market Segment, Technology, and Application. https://www.navigantresearch.com/reports/smart-city-tracker-1q18 Accessed 09 April 2019.

59. Oliver, A. \& Pearl, D. S. (2018). Rethinking sustainability frameworks in neighbourhood projects: a process-based approach. Building Research \& Information, 46(5), 513-527. DOI: 10.1080/09613218.2017.1358569

60. Phills, J. A., Deiglmeier, K., \& Miller, D. T. (2008). Rediscovering social innovation. Stanford Social Innovation Review, 6(4), 34-43. DOI:

61. Place Standard. (n.d.). How good is our place? https://www.placestandard.scot/ Accessed 20 June 2018.

62. Planning Aid Scotland. (n.d.). Place Standard App. https://www.pas.org.uk/news/place-standard-app/ Accessed 20 June 2018. 
63. Reason, P., \& Bradbury, H. (Eds.). (2001). Handbook of action research: Participative inquiry and practice. Sage.

64. Robinson, J. (2004). Squaring the circle? Some thoughts on the idea of sustainable development. Ecological economics, 48(4), 369-384. DOI: https://doi.org/10.1016/j.ecolecon.2003.10.017

65. Ruiz, C. and Parra, C. (2013), in Viñals, C. R., \& Rodríguez, C. P. (Eds.). (2013). Social Innovation: New Forms of Organisation in Knowledge-Based Societies. Routledge.

66. Saviano, M., Caputo, F., Formisano, V. \& Walletzký, L. (2016). From theory to practice: applying systems thinking to Smart Cities. In Caputo, F. (ed) Governing Business Systems. Theory and Challenges for Systems Thinking in Practice, $4^{\text {th }}$ Business Systems Laboratory International Symposium, 24-26 August 2016. Vilnius: Mykoloas Romeris University, pp. 35-40.

67. Schaffers, H., Komninos, N., Pallot, M., Trousse, B., Nilsson, M. \& Oliveira, A. (2011). Smart Cities and the Future of Internet: Towards Cooperation Frameworks for Open Innovation. In: Domingue J. et al. (eds) The Future Internet. FIA 2011. Lecture Notes in Computer Science, vol 6656. Berlin and Heidelberg: Springer. DOI: 10.1007/978-3-642-20898-0_31.

68. Scottish Government (2014). Ambition - Opportunity - Place: Scotland's Third National Planning Framework. http://www.gov.scot/Resource/0045/00453683.pdf/ Accessed 20 June 2018.

69. Scottish Government (2015). Community Empowerment (Scotland) Act: summary. https://beta.gov.scot/publications/community-empowerment-scotland-act-summary/ Accessed 20 June 2018.

70. Scottish Government (2016). National Standards for Community Engagement. http://www.gov.scot/Resource/Doc/94257/0084550.pdf/ Accessed 20 June 2018.

71. Scottish Government and Architecture and Design Scotland (2017). Place Standard process evaluation: learning from case studies in year one. http://www.healthscotland.scot/media/1394/place-standardprocess-evaluation_may2017_english.pdf/ Accessed 20 June 2018.

72. Scottish Government (2018b). National Outcomes for Scotland (Revised). http://www.parliament.scot/parliamentarybusiness/CurrentCommittees/108188.aspx/ Accessed 20 June 2018.

73. Scottish Government (2018a). Planning (Scotland) Bill. www.parliament.scot/parliamentarybusiness/Bills/106768.aspx/ Accessed 20 June 2018.

74. Semiletova, L. (2011). Problems Arising from Land Privatization by a Building Owner. The Moscow Times, 23 August. https://themoscowtimes.com/articles/problems-arising-from-land-privatization-bya-building-owner-9073/ Accessed 20 June 2018.

75. Shelton, T., Zook, M., \& Wiig, A. (2015). The 'actually existing smart city'. Cambridge Journal of Regions, Economy and Society, 8(1), 13-25. DOI: 10.1093/cjres/rsu026.

76. Singer, N. (2012). Mission Control, Built for Cities: I.B.M. Takes 'Smarter Cities' Concept to Rio de Janeiro. New York Times, 3 March. https://www.nytimes.com/2012/03/04/business/ibm-takessmarter-cities-concept-to-rio-de-janeiro.html/ Accessed 9 November 2018.

77. Stott, R. (2013) Does the Title of "Architect" Deserve To Be Protected? ArchDaily, 7 November. https://www.archdaily.com/446771/does-the-title-of-architect-deserve-to-be-protected/ Accessed 9 November 2018.

78. The Scottish Council for Voluntary Organisations (2018). The Global Goals for Sustainable Development: Scotland's Goals. https://globalgoals.scot/scotlands-goals/ Accessed 20 June 2018.

79. Townsend, A. (2013). Smart Cities: Buggy and Brittle. Places Journal. https://placesjournal.org/article/smart-cities/ Accessed 9 November 2018.

80. United Nations (1992). Agenda 21: programme of action for sustainable development, Rio Declaration on Environment and Development, statement of forest principles: the final text of agreements negotiated by Governments at the United Nations Conference on Environment and Development (UNCED), 3-14 June, Rio de Janeiro, Brazil. http://dag.un.org/handle/11176/376732/ Accessed 20 June 2018. 
81. United Nations (2015). Sustainable Development Goals. https://sustainabledevelopment.un.org/?menu=1300/ Accessed 20 June 2018.

82. United Nations Economic Commission for Europe (UNECE) (2004). Country Profiles on the Housing Sector: Russian Federation.

https://www.unece.org/fileadmin/DAM/hlm/documents/2005/ECE/hbp/ECE_HBP_131.e.pdf/ Accessed 20 June 2018.

83. Vasudevan, A. (2015). The makeshift city: Towards a global geography of squatting. Progress in Human Geography, 39(3), 338-359. DOI: 10.1177/0309132514531471

84. Von Jacobi, N., Edmiston, D., \& Ziegler, R. (2017). Tackling marginalisation through social innovation? Examining the EU social innovation policy agenda from a capabilities perspective. Journal of Human Development and Capabilities, 18(2), 148-162. DOI: https://doi.org/10.1080/19452829.2016.1256277

85. Wainwright, O. (2014). The truth about property developers: how they are exploiting planning authorities and ruining our cities. The Guardian, 17 September. https://www.theguardian.com/cities/2014/sep/17/truth-property-developers-builders-exploitplanning-cities/ Accessed 20 June 2018.

86. Walker, B., Holling, C. S., Carpenter, S. R., \& Kinzig, A. (2004). Resilience, adaptability and transformability in social-ecological systems. Ecology and society, 9(2). DOI: https://doi.org/10.5751/es-00650-090205

Acknowledgments: PhD studentship has been provided by the University of Strathclyde and Building Research Establishment Trust. The author would like to thank interviewees who participated in the research to date.

Author Contributions: This paper has been written by Donagh Horgan with supervision by Branka Dimitrijević.

Conflicts of Interest: The authors declare no conflict of interest. 